\title{
Pelatihan Pembuatan Modul Ajar Bagi Guru SMA/SMK di Tebing Tinggi
}

\author{
Nila Kesumawati ${ }^{1}$, Destiniar ${ }^{2}$, Dina Octaria*33, Yunika Lestaria Ningsih ${ }^{4}$, Putri \\ Fitriasari $^{5}$, Anggria Septiani Mulbasari ${ }^{6}$, Tika Dwi Nopriyanti ${ }^{7}$, Allen Marga Retta $^{8}$ \\ dinaoctaria@univpgri-palembang.ac.id ${ }^{* 3}$ \\ 1,2,3,4,5,6,7,8 Pendidikan Matematika, Universitas PGRI Palembang
}

Received: 01 November 2021 Accepted: 06 December 2021 Online Published: 30 December 2021 DOI: 10.29408/ab.v2i2.4586

\begin{abstract}
Abstrak: Peningkatan mutu pembelajaran di sekolah dilakukan dengan berbagai strategi, salah satu diantaranya melalui pengembangan bahan ajar. Pengembangan bahan ajar dalam bentuk modul saat ini menjadi kebutuhan yang sangat mendesak. Hal ini dikarenakan penerapan modul dapat mengondisikan kegiatan pembelajaran lebih terencana dengan baik, mandiri, tuntas dan dengan hasil (output) yang jelas, sehingga pendidik dapat membantu sekolah dalam mewujudkan pembelajaran yang berkualitas. Namun, kenyataannya banyak pendidik yang kesulitan dalam membuat modul ajar yang sesuai dengan kebutuhan peserta didik. Ini dikarenakan kurangnya pengetahuan dan kurangnya pelatihan bagi pendidik dalam membuat modul ajar yang efektif. Oleh karena itu, kegiatan PKM ini bertujuan 1) untuk mengenalkan dan membekali pendidik tentang modul ajar, 2) untuk membantu pendidik dalam membuat modul ajar. Metode pelaksanaan yang digunakan dalam kegiatan ini adalah ceramah, praktik dan diskusi. Pelaksanaan kegiatan dilakukan secara online menggunakan aplikasi Zoom dan offline di SMA Negeri 2 Tebing Tinggi Empat Lawang. Langkah-langkah dalam kegiatan PKM yaitu 1) persiapan, 2) pelaksanaan, 3) refleksi. Data dikumpulkan melalui angket. Hasil pelaksanaan kegiatan PKM menunjukkan bahwa kegiatan pelatihan berjalan dengan lancar dan peserta kegiatan antusias dalam mengikuti pelatihan. Dari hasil analisis data dapat disimpulkan bahwa $72,8 \%$ peserta kegiatan menyatakan bahwa kegiatan pelatihan ini dapat menambah pengetahuan dan pemahaman tentang modul dan 83,3\% menyatakan bahwa kegiatan pelatihan ini dapat melatih keterampilan pendidik dalam membuat modul. Kegiatan ini mampu memberikan sumbangsih bagi pendidik dalam menghasilkan modul yang efektif untuk digunakan dalam proses pembelajaran.
\end{abstract}

Kata kunci: Bahan Ajar; Pelatihan; Modul Ajar

Abstract: Improving the quality of learning in schools is carried out by various strategies, one of which is developing teaching materials. The development of teaching materials in modules is currently a very urgent need. Because the application of the module can make learning activities more well-planned, independent, complete, and precise results so that educators can assist schools in realizing quality learning. However, in reality, many educators have difficulty making teaching modules that suit the needs of students. Due to educators' lack of knowledge and training to make teaching modules. Therefore, this PKM activity aims 1) to introduce and equip educators about teaching modules, 2) to assist educators in making teaching modules. The implementation method used in this activity is lecture, practice, and discussion. The activities were conducted online using the Zoom application and offline at SMA Negeri 2 Tebing Tinggi Empat Lawang. The steps in PKM activities are 1) preparation, 2) implementation, 3) reflection. Data was collected through a questionnaire. The implementation of PKM activities showed that the training activities ran smoothly, and the participants were enthusiastic about participating in the training. From the results of data analysis, it can be concluded that $72.8 \%$ of the participants stated that this training activity could increase their knowledge and understanding of the module, and $83.3 \%$ stated that this training activity could train the skills of educators in doing modules. This activity can contribute to educators producing practical modules to use in the learning process.

Keywords: Teaching materials; Teaching Module; Training 
Kesumawati, N., Destiniar, D., Octaria, D., Ningsih, Y. L., Fitriasari, P., Mulbasari, A. S., Nopriyanti, T. D., Retta, A. M. (2021). Pelatihan pembuatan Modul Ajar bagi guru SMA/SMK di Tebing Tinggi. ABSYARA: Jurnal Pengabdian Pada Masyarakat, 2(2), $246-256$. doi:10.29408/ab.v2i2.4589

\section{PENDAHULUAN}

Kemajuan teknologi informasi memberikan banyak kemudahan dalam kehidupan manusia termasuk untuk memecahkan masalah pendidikan dan pengembangan sumber daya manusia di Indonesia, terlebih lagi pada masa pandemi Covid-19. Pada saat ini pemerintah mengeluarkan berbagai kebijakan untuk melakukan perubahan dalam lini kehidupan manusia, tanpa terkecuali dunia pendidikan (Syamsuri, dkk., 2021). Salah satu permasalahan yang dihadapi dalam dunia pendidikan yaitu lemahnya proses pembelajaran (Hidayah, 2015). Menurut Rampengan, banyak kritik yang ditujukan pada para pendidik dalam proses pembelajaran yang menekankan pada informasi/konsep yang diberikan pendidik kepada peserta didik hanya satu arah (Zaenudin, 2015). Disisi lain, Undang-undang No. 14 tahun 2005 ayat (10) mengisyaratkan bahwa pendidik tidak hanya dituntut sebagai pengajar, akan tetapi juga sebagai tenaga profesional yang dapat melaksanakan pekerjaannya sebagai pengajar dan dapat meningkatkan mutu pembelajaran melalui cara yang sistematis.

Peningkatan mutu pembelajaran di sekolah dapat dilakukan dengan berbagai strategi, salah satu diantaranya melalui pembuatan bahan ajar yang kontekstual dan dapat dipelajari secara mandiri (Rachman, dkk., 2017; Kholisho, dkk., 2021). Modul merupakan salah satu bahan ajar yang disusun secara sistematis dan menarik baik dari segi isi materi, metode dan evaluasi yang dapat digunakan secara mandiri (Anwar, 2010). Modul pembelajaran yang baik memiliki karakteristik, seperti memuat tujuan pembelajaran yang jelas, memuat materi pembelajaran yang dikemas dalam unit-unit kegiatan, tersedia contoh dan ilustrasi yang mendukung kejelasan pemaparan materi, terdapat soal-soal latihan, kontekstual, menggunakan bahasa yang sederhana dan komunikatif, terdapat rangkuman, instrumen penilaian, umpan balik, terdapat referensi, tidak bergantung pada bahan ajar lain, memiliki daya adaptasi yang tinggi terhadap perkembangan ilmu dan teknologi, serta mudah digunakan (Dharma, 2008).

Beberapa penelitian terdahulu menunjukkan bahwa modul efektif digunakan dalam pembelajaran. Modul dapat melatih peserta didik baik secara kognitif, keterampilan maupun afektif (Septiani, 2016; Samsuri, dkk., 2020; Sutisna \& Elkarimah, 2021). Modul juga dapat memudahkan peserta didik berlatih soal-soal secara mandiri dan dapat meningkatkan kemampuan pemecahan masalah peserta didik (Nurmeidina, Lazwardi, \& Nugroho, 2021). Namun, fakta di lapangan menunjukkan peserta didik masih mengalami kesulitan dalam memahami materi di buku paket, masih sedikitnya modul yang dikembangkan oleh pendidik untuk menunjang proses pembelajaran di dalam kelas (Utami, Jatmiko, \& Suherman, 2018), buku ajar yang beredar di pasaran sudah dapat dikatakan bagus, namun belum maksimal dalam melatih kemampuan berpikir kritis (Millah, Budipramana, \& Isnawati, 2012), serta belum banyak pendidik yang memahami dan memiliki keterampilan yang memadai dalam hal pengembangan dan penggunaan bahan ajar dalam proses pembelajaran (Ramadhani, Mazaly, \& Setiawati, 2021).

Pembuatan modul sangat penting dan membantu peserta didik dalam pembelajaran, namun pendidik masih banyak yang kurang terlatih dalam membuat modul ajar, hal ini dikarenakan pendidik memiliki kesibukan dengan kegiatan mengajar di kelas dan kegiatan di sekolah, serta pendidik menganggap bahwa membuat modul ajar itu sulit dan membutuhkan waktu yang lama (Nawawi, dkk., 2017). Pelatihan pembuatan modul ajar sangat dibutuhkan, hal ini dikarenakan di sekolah mitra yang ada di Tebing Tinggi belum pernah membuat dan 
mengembangkan modul ajar kreatif inovatif, sehingga produktivitas pendidik dalam menghasilkan modul ajar kreatif inovatif rendah. Rendahnya produktivitas tersebut disebabkan beberapa hal, yaitu pengetahuan pendidik di sekolah mitra untuk membuat modul ajar masih kurang, kemampuan mengabstraksi dan berimajinasi pendidik masih rendah, serta belum ada pihak yang memotivasi dan peduli terhadap penerbitan produk modul ajar yang dihasilkan pendidik di sekolah (Zuriah, Sunaryo, \& Yusuf, 2016). Oleh karena itu, sebagai upaya untuk menambah pengetahuan dan keterampilan pendidik dalam pembuatan modul ajar, tim pengabdian kepada masyarakat program studi pendidikan matematika Universitas PGRI Palembang merasa perlu untuk melakukan kegiatan pelatihan pembuatan modul ajar bagi pendidik SMA/SMK di Tebing Tinggi. Adapun tujuan kegiatan PKM ini adalah: 1) untuk mengenalkan dan membekali pendidik tentang modul ajar, 2) untuk membantu pendidik dalam membuat modul ajar

\section{METODE PELAKSANAAN}

\section{Waktu dan Lokasi}

Kegiatan pengabdian dilaksanakan dari tanggal 4 Mei 2021 sampai dengan 2 Juni 2021. Pelaksanaan kegiatan dilakukan secara online (menggunakan aplikasi Zoom) dan offline di SMA Negeri 2 Tebing Tinggi Empat Lawang. Kegiatan ini diikuti oleh 42 orang yang terdiri dari 8 orang dosen sebagai penyaji, 2 orang mahasiswa, 2 orang panitia dan 30 orang peserta yaitu pendidik yang mengajar beberapa mata pelajaran di SMA/SMK Negeri Tebing Tinggi. Peserta kegiatan ini terdiri dari 22 orang perempuan dan 8 orang laki-laki, dengan rentang usia 40 - 50 tahun serta mengajar mata pelajaran matematika, bahasa Inggris, bahasa Indonesia, Biologi, Fisika, sejarah, dan Agama Islam. Data dalam kegiatan ini dikumpulkan melalui angket, kemudian dianalisis menggunakan statistik deskriptif kualitatif

\section{Prosedur pelaksanaan}

Alat dan bahan yang digunakan dalam pelatihan ini adalah beberapa contoh modul yang telah disiapkan oleh penyaji, laptop yang digunakan oleh masing-masing peserta, aplikasi Zoom berbayar selama 1 bulan dan Whatsapp Group yang dijadikan sebagai sarana untuk memberikan informasi serta sebagai tempat diskusi lanjutan. Kegiatan ini dilaksanakan dengan metode ceramah, diskusi, praktik dan presentasi. Metode kegiatan dapat dilihat pada Tabel 1.

Tabel 1. Metode Pelaksanaan Kegiatan PKM

\begin{tabular}{cl}
\hline Metode & \multicolumn{1}{c}{ Deskripsi } \\
\hline Ceramah & $\begin{array}{l}\text { Metode ini dilakukan di awal kegiatan dan ditujukan untuk } \\
\text { menyampaikan materi tentang modul, metode ceramah ini } \\
\text { dilakukan secara } \text { online }\end{array}$ \\
\hline Praktik dan & $\begin{array}{l}\text { Dalam pembuatan modul, peserta melakukan metode } \\
\text { praktik dan diskusi, diskusi yaitu tanya jawab peserta } \\
\text { dengan tim instruktur, metode diskusi dilakukan pada saat } \\
\text { praktik secara online dan melalui Whatsapp group }\end{array}$
\end{tabular}


Kesumawati, N., Destiniar, D., Octaria, D., Ningsih, Y. L., Fitriasari, P., Mulbasari, A. S., Nopriyanti, T. D., Retta, A. M. (2021). Pelatihan pembuatan Modul Ajar bagi guru SMA/SMK di Tebing Tinggi. ABSYARA: Jurnal Pengabdian Pada Masyarakat, 2(2), $246-256$. doi:10.29408/ab.v2i2.4589

Presentasi Metode ini dilakukan pada saat offline/ tatap muka, perwakilan peserta mempresentasikan/ menampilkan modul yang telah dibuat

Langkah-langkah yang ditempuh dalam kegiatan PKM ini yaitu:

1. Persiapan

Tahap persiapan merupakan tahapan awal sebelum pelaksanaan PKM. Ada beberapa hal yang dilakukan pada tahap ini, yaitu koordinasi internal dilakukan oleh tim, penentuan peserta pelatihan, dan pembuatan materi dan instrumen PKM.

2. Pelaksanaan

Pelaksanaan kegiatan dilakukan berdasarkan mekanisme dan rancangan umum kegiatan pelatihan yang dikoordinasikan dengan LPPKM Universitas PGRI Palembang. Pelaksanaan kegiatan dilakukan secara online (menggunakan aplikasi Zoom) dan secara offline di SMA Negeri 2 Tebing Tinggi. Pelatihan ini dilaksanakan dari tanggal 4 Mei 2021 sampai dengan 2 Juni 2021. Adapun jadwal kegiatan pelatihan dapat dilihat pada Tabel 2.

Tabel 2. Jadwal Kegiatan Pengabdian kepada Masyarakat

\begin{tabular}{clc}
\hline No. & \multicolumn{1}{c}{ Kegiatan } & $\begin{array}{c}\text { Waktu } \\
\text { (Jam Pembelajaran) }\end{array}$ \\
\hline 1. & Analisis Materi & $2 \mathrm{JP}$ \\
2. & Karakteristik Modul & $2 \mathrm{JP}$ \\
3. & Peta Modul dan Desain Modul & $2 \mathrm{JP}$ \\
4. & Menyusun Kerangka Modul & $2 \mathrm{JP}$ \\
5. & Implementasi Karakteristik Modul & $2 \mathrm{JP}$ \\
6. & Asynchronous & 8 JP \\
7. & Offline/Tatap muka & 4 JP \\
\hline & Jumlah jam pelajaran
\end{tabular}

3. Refleksi

Refleksi adalah aktivitas berupa penilaian terhadap kegiatan yang telah dilaksanakan. Penilaian dilakukan dengan cara mengisi angket yang dibuat dalam bentuk Google Form dan dibagikan dalam format link.

\section{HASIL DAN PEMBAHASAN}

\section{HASIL}

Kegiatan Pengabdian kepada Masyarakat ini dilaksanakan dari tanggal 4 Mei 2021 sampai dengan tanggal 2 Juni 2021. Kegiatan ini terbagi menjadi 4 sesi.

\section{Sesi Pertama}

Sesi pertama dilaksanakan pada hari Selasa, 4 Mei 2021 secara online melalui aplikasi Zoom. Sesi pertama ini merupakan pembukaan kegiatan PKM yang dihadiri oleh Dekan FKIP Universitas PGRI Palembang, Kepala Sekolah SMA/SMK di Tebing Tinggi, peserta dan tamu undangan lainya. Kegiatan ini berlangsung secara synchronous dan asynchronous berlangsung dari pukul $09.00-16.00$ WIB. 
Pelaksanaan secara synchronous berlangsung dari pukul 09.00 - 14.00 WIB dengan materi yang disajikan yaitu: analisis materi dan karakteristik modul. Pada sesi pertama penyaji menyampaikan tentang analisis materi yang mencakup kegiatan mengidentifikasi dan menganalisis silabus, RPP, standar kompetensi yang akan dipelajari, kompetensi dasar dan tujuan pembelajaran, menyusun dan mengorganisasi satuan atau unit bahan belajar, serta menyampaikan langkah penyusunan modul berdasarkan prioritas kebutuhan. Penyaji selanjutnya menyampaikan tentang karakteristik apa saja yang harus ada pada modul yaitu self instruction, self contained, stand alone, adaptif, dan user friendly.

Kegiatan PKM ini secara asynchronous berlangsung dari pukul 14.00 - 16.00 WIB, pada sesi pertama setiap peserta mulai menyiapkan bahan dan materi untuk pembuatan modul, dan mulai membuat modul secara asynchronous dengan tetap melakukan diskusi di Whatsapp Group jika mengalami kesulitan.

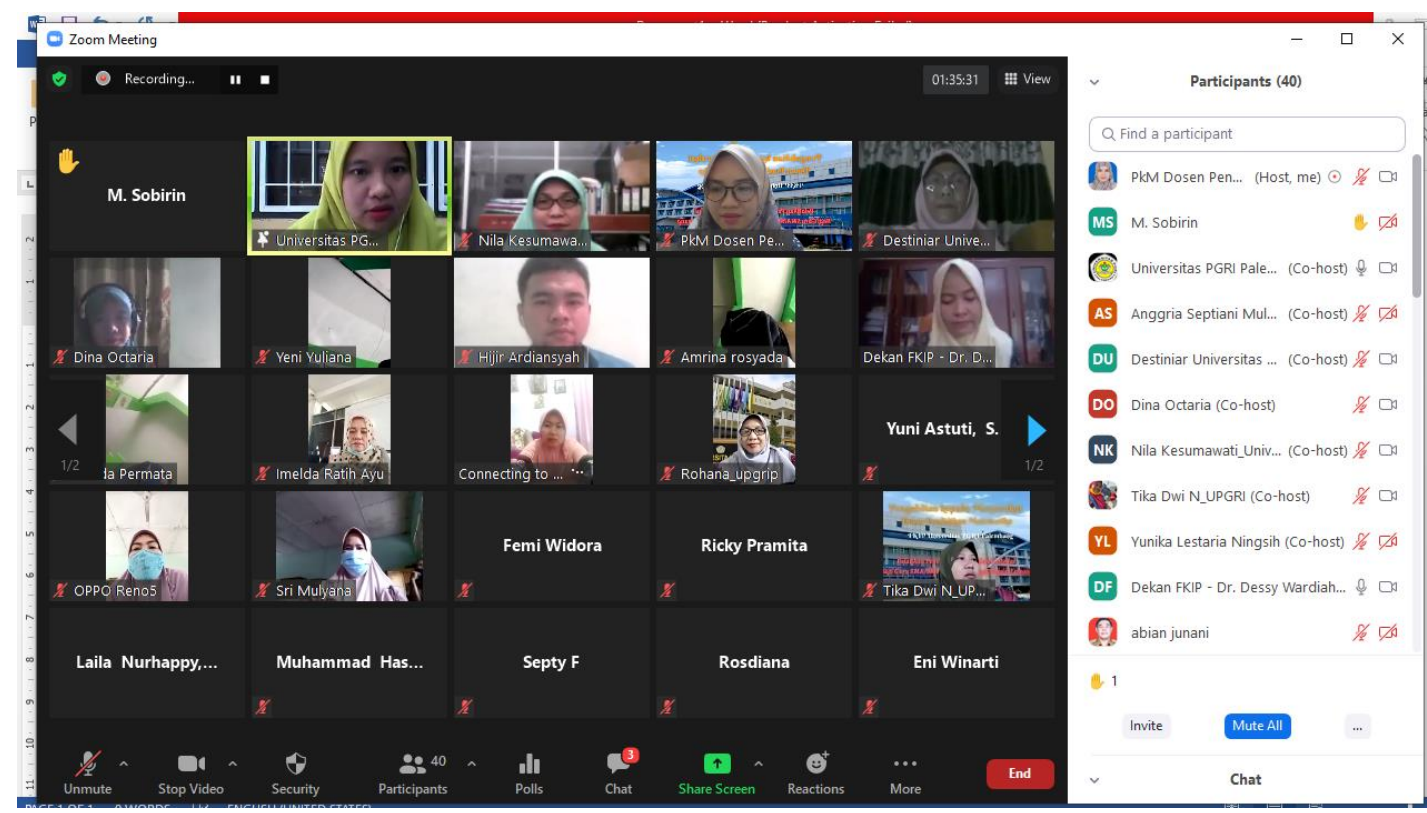

Gambar 1. Kegiatan Pelatihan Sesi 1 Pembukaan Kegiatan PKM, Penyajian Materi Analisis Materi dan Karakteristik Modul

\section{Sesi Kedua}

Sesi kedua dilaksanakan pada hari Kamis, 6 Mei 2021 secara online melalui aplikasi Zoom. Pada sesi kedua ini kegiatan tetap berlangsung secara synchronous dan asynchronous. Secara synchronous kegiatan berlangsung dari pukul 09.00 - 11.00 WIB dengan materi yang disajikan yaitu peta modul dan desain modul yang mencakup kegiatan menyusun peta modul berdasarkan diagram pencapaian kompetensi yang termuat dalam kurikulum, mendesain modul dengan memperhatikan strategi pembelajaran, media yang digunakan, garis besar materi pembelajaran, kebutuhan peserta didik, dan metode penilaian serta perangkatnya.

Kegiatan PKM pada sesi kedua secara asynchronous berlangsung dari pukul 11.00 16.00 WIB, masing-masing peserta tetap melanjutkan pembuatan modul sesuai materi yang telah diberikan, tim memantau dan mendampingi peserta melalui Whatsapp Group. Pada sesi kedua masing-masing peserta telah melakukan analisis materi, secara garis besar peserta telah membuat peta modul dan mendesain modul dengan membuat storyboard. 

pembuatan Modul Ajar bagi guru SMA/SMK di Tebing Tinggi. ABSYARA: Jurnal Pengabdian Pada Masyarakat, 2(2), $246-256$. doi:10.29408/ab.v2i2.4589

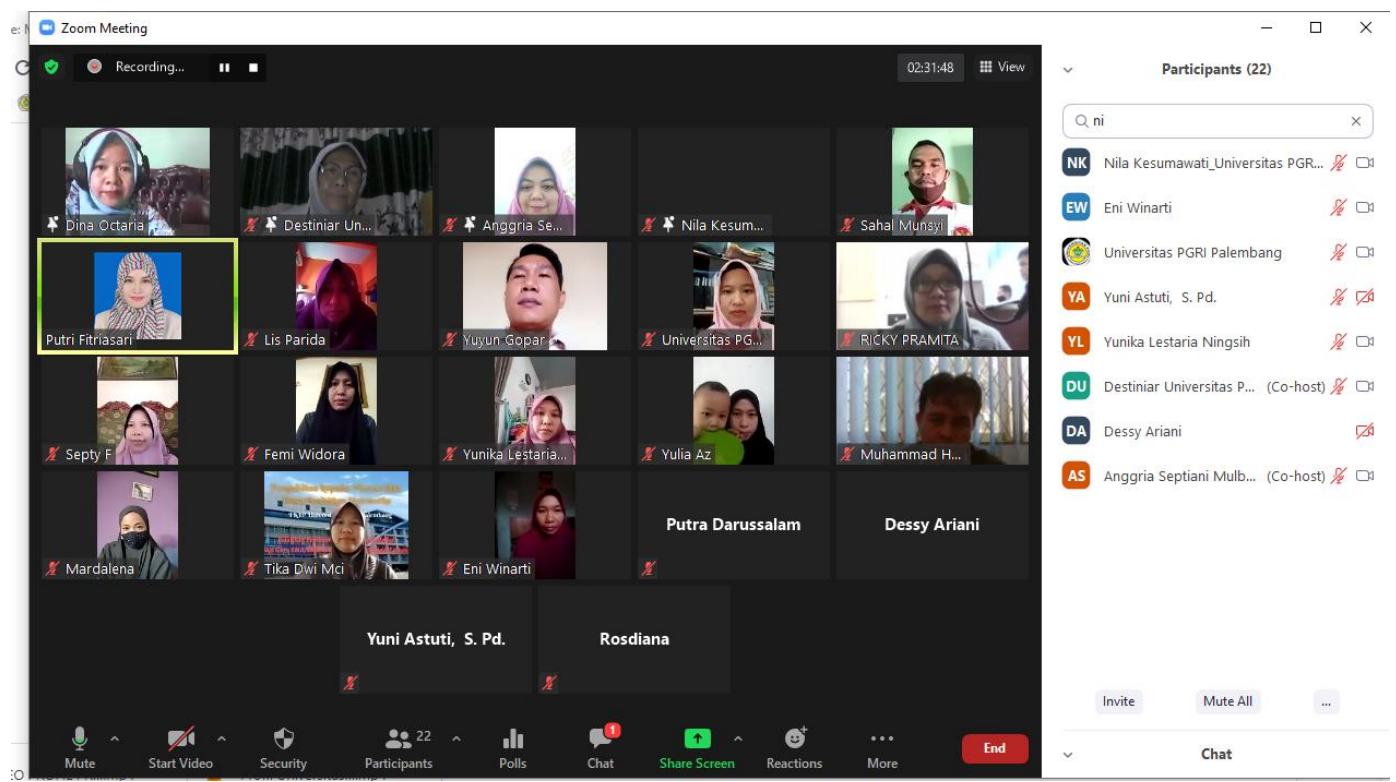

Gambar 2. Kegiatan Pelatihan Sesi 2 Peta Modul dan Desain Modul

\section{Sesi Ketiga}

Sesi ketiga dilaksanakan pada hari Sabtu, 8 Mei 2021 secara online melalui aplikasi Zoom. Pada sesi ketiga ini kegiatan berlangsung secara synchronous dan asynchronous. Secara synchronous kegiatan berlangsung dari pukul 09.00 - 14.00 WIB dengan materi yang disajikan yaitu menyusun kerangka dan implementasi karakteristik modul. Penyaji menyampaikan tentang bagaimana menyusun kerangka modul mencakup membuat halaman sampul, kata pengantar, daftar isi, peta kedudukan modul, glosarium, pendahuluan, pembelajaran, evaluasi dan penutup. Pendahuluan pada kerangka modul terdiri dari standar kompetensi, deskripsi, waktu, prasyarat, petunjuk penggunaan modul, tujuan akhir, cek penguasaan standar kompetensi. Bagian pembelajaran terdiri dari tujuan pembelajaran, uraian materi, rangkuman, tugas, tes dan lembar kerja praktik. Bagian evaluasi terdiri dari tes kognitif, tes psikomotor, penilaian sikap, kunci jawaban, dan daftar pustaka, serta bagian akhir penutup.

Penyaji menyampaikan materi selanjutnya yaitu tentang implementasi karakteristik modul harus dilaksanakan sesuai dengan alur yang telah dibuat dalam modul. Bahan, alat, media dan lingkungan belajar yang dibutuhkan dalam kegiatan pembelajaran diupayakan dapat dipenuhi agar tujuan pembelajaran dapat tercapai. Kegiatan PKM pada sesi ketiga secara asynchronous berlangsung dari pukul 14.00 - 16.00 WIB, peserta melanjutkan pembuatan modul dengan pemantauan dan bimbingan oleh tim melalui Whatsapp Group, sehingga pada sesi ini dihasilkan kerangka modul. 


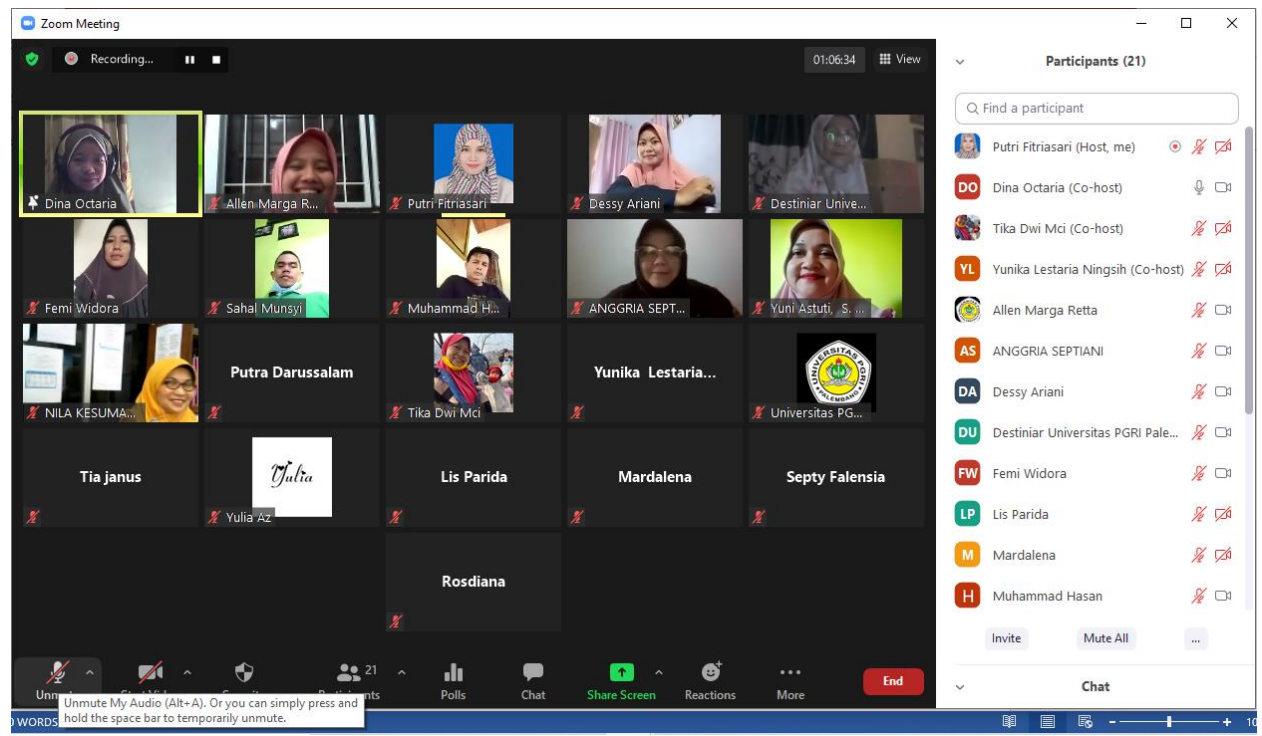

Gambar 3. Kegiatan Pelatihan Sesi 3 Menyusun Kerangka dan Implementasi Karakteristik Modul

\section{Sesi Keempat}

Sesi keempat dilaksanakan pada hari Rabu, 2 Juni 2021 secara offline bertempat di SMA Negeri 2 Tebing Tinggi. Sesi keempat ini merupakan penutupan kegiatan PKM yang dihadiri oleh tim LPPKM Universitas PGRI Palembang, Kepala Sekolah SMA/SMK di Tebing Tinggi, peserta dan tamu undangan lainnya. Pada sesi ini dilakukan pemaparan hasil produk yang dibuat peserta kegiatan pelatihan yang berlangsung selama kurang lebih 1 bulan, produk yang dihasilkan berupa modul ajar dari masing-masing peserta, dari pemaparan modul ajar yang sudah dibuat peserta terlihat bahwa modul yang dibuat peserta sudah memenuhi semua komponen modul ajar, perbedaannya terletak pada desain modul yang bergantung pada kreativitas dari peserta tersebut. Untuk melihat ketercapaian sasaran kegiatan PKM, peserta diharuskan untuk mengisi angket respons peserta terhadap kegiatan pelatihan.

Kegiatan pengabdian kepada masyarakat berupa pelatihan pembuatan modul sangat bermanfaat, hal ini terlihat dari hasil angket yang menunjukkan rata-rata persentase sebesar $81,32 \%$. Persentase terbesar terdapat pada pernyataan "Saya akan membuat modul saya sendiri" yaitu sebesar $87,1 \%$, ini berarti peserta didik sudah memiliki keinginan yang besar untuk membuat modul ajar secara berkelanjutan. Sedangkan persentase terkecil terdapat pada pernyataan "Modul dapat mempermudah peserta didik untuk belajar di mana saja dan kapan saja" serta pada pernyataan "Pelatihan ini dapat meningkatkan kemampuan pendidik dalam membuat modul ajar" yaitu sebesar 72,8\%, meskipun tergolong persentase terkecil namun masih dikategorikan baik, artinya pelatihan ini memberikan kontribusi terhadap pendidik dalam membekali dan membimbing pendidik membuat modul ajar. Hasil dari kegiatan PKM dapat dilihat pada tabel 3 .

Tabel 3. Hasil Angket Kegiatan Pengabdian kepada Masyarakat

\begin{tabular}{clc}
\hline No. & \multicolumn{1}{c}{ Pernyataan } & Persentase \\
\hline 1. & $\begin{array}{l}\text { Pelatihan ini sangat bermanfaat terhadap } \\
\text { pembelajaran }\end{array}$ & $76,7 \%$ \\
\hline 2. & Saya antusias mengikuti pelatihan ini & $85,6 \%$ \\
\hline
\end{tabular}




\begin{tabular}{lll}
\hline 3. & $\begin{array}{l}\text { Modul dapat mempermudah peserta didik untuk } \\
\text { belajar di mana saja dan kapan saja }\end{array}$ & $72,8 \%$ \\
\hline 4. & $\begin{array}{l}\text { Pelatihan ini dapat meningkatkan keterampilan } \\
\text { pendidik dalam membuat modul }\end{array}$ & $83,3 \%$ \\
\hline 5. & $\begin{array}{l}\text { Saya ingin menggunakan modul dalam } \\
\text { pembelajaran }\end{array}$ & $85,3 \%$ \\
\hline 6. & Saya akan membuat modul saya sendiri & $87,1 \%$ \\
\hline 7. & Materi pelatihan ini sesuai dengan kebutuhan & $84,6 \%$ \\
\hline 8. & $\begin{array}{l}\text { Kemampuan instruktur sudah sesuai dengan } \\
\text { harapan }\end{array}$ & $86,7 \%$ \\
\hline 9. & $\begin{array}{l}\text { Pelatihan ini dapat meningkatkan kemampuan } \\
\text { pendidik dalam membuat modul }\end{array}$ & $72,8 \%$ \\
\hline 10. & Metode pelatihan sesuai dengan jenis penelitian & $78,3 \%$ \\
\hline
\end{tabular}

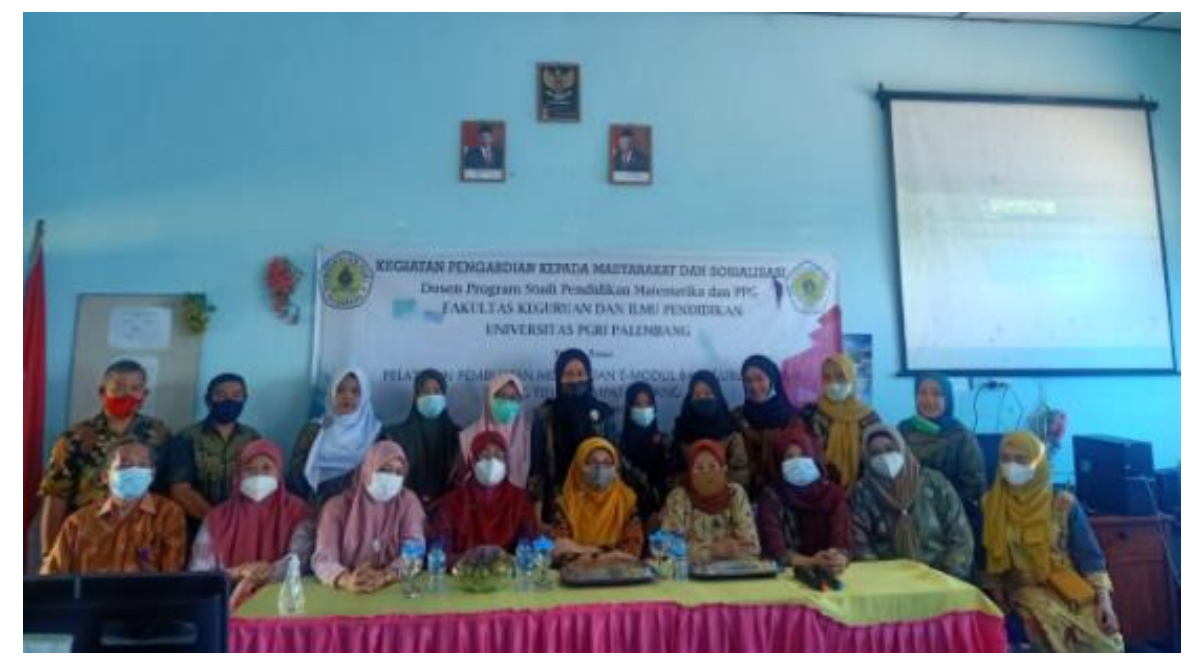

Gambar 4. Kegiatan Pelatihan Sesi 4 Penutupan Pengabdian kepada Masyarakat

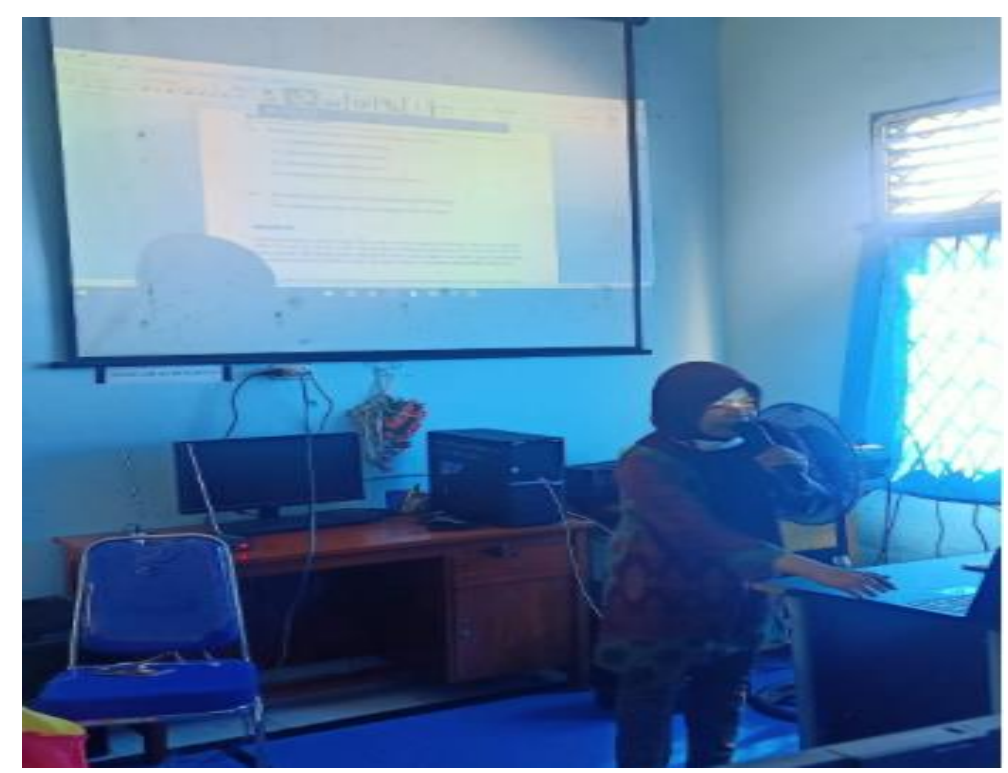

Gambar 5. Kegiatan Pelatihan Sesi 4 Peserta sedang mempresentasikan modul yang telah dibuat 


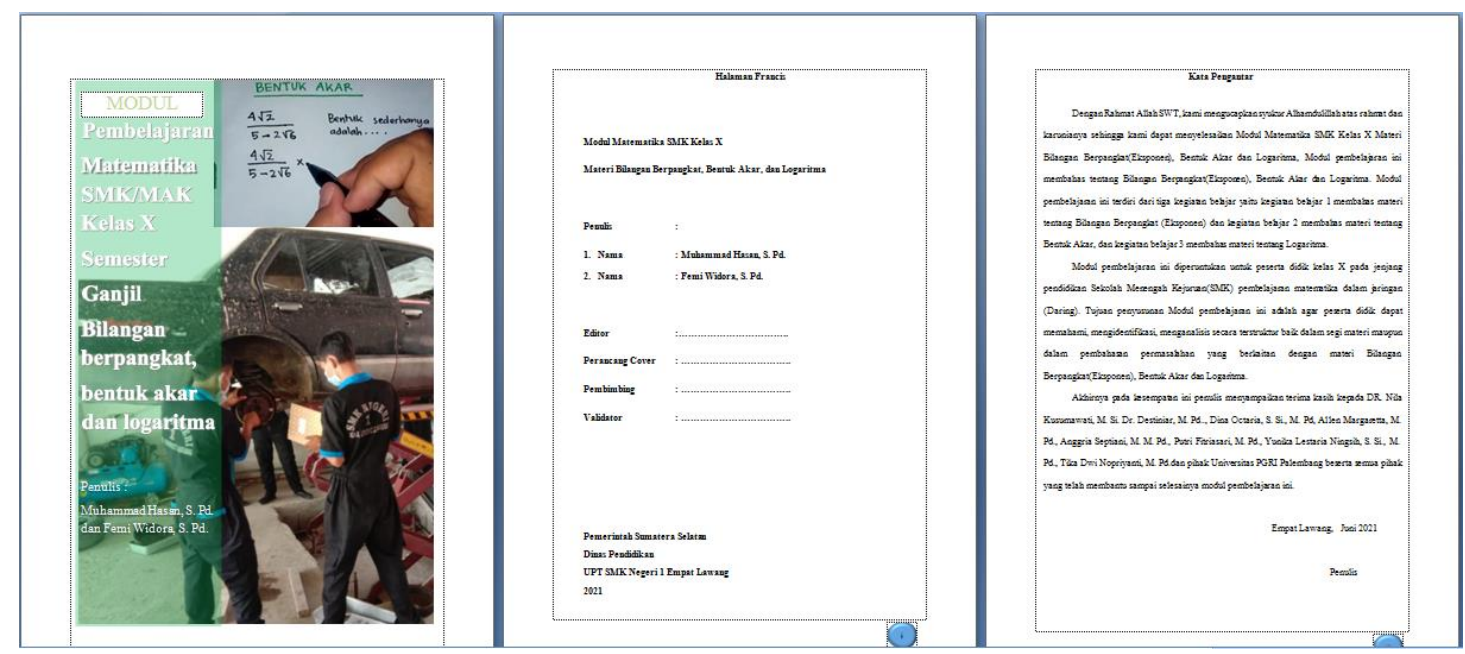

Gambar 6. Modul Ajar Hasil Karya Peserta

\section{PEMBAHASAN}

Proses pelaksanaan kegiatan PKM berjalan dengan lancar dan baik, namun sedikit terkendala di jaringan. Letak sekolah yang berada di daerah dan kegiatan dilaksanakan secara online melalui aplikasi Zoom, terkadang menjadi kendala jika terjadi hujan deras yang mengakibatkan sinyal hilang dan peserta sulit untuk mengakses aplikasi Zoom. Kendala jaringan internet dalam proses pembelajaran ini sejalan dengan hasil penelitian yang dilakukan oleh (Rigianti, 2020). Namun, dalam proses pelaksanaan peserta terlihat aktif dan antusias mengikuti kegiatan. Peserta mendapatkan pengalaman baru, menambah wawasan, dan mengetahui cara membuat modul ajar. Hal ini senada dengan kegiatan yang dilakukan oleh (Nawawi, Antika, Wijayanti, \& Abadi, 2018). Penggunaan modul dalam pembelajaran sangat bermanfaat bagi pendidik dan peserta didik, modul dapat membantu peserta didik dalam menemukan konsep, sehingga peserta didik terbantu untuk belajar mandiri. Penggunaan modul dapat mengondisikan kegiatan pembelajaran lebih terencana dengan baik, mandiri, tuntas dan dengan hasil yang baik (Daryanto, 2014).

Pada saat pelatihan, sebagian besar peserta telah membuat modul untuk bidang studi masing-masing. Hal ini terlihat dari hasil angket pada poin 5 dan 6 yang menyatakan bahwa saya akan membuat modul dan ingin menggunakan modul tersebut dalam pembelajaran, artinya peserta/pendidik sudah mempunyai keinginan untuk membuat dan menggunakan modul yang mereka buat sendiri dalam pembelajaran secara berkesinambungan. Peserta membutuhkan waktu yang agak lama untuk membuat modul, hal ini sejalan dengan hasil penelitian yang dilakukan oleh (Mufidah \& Susilawati, 2019). Sehingga pada saat pelatihan sesi 4 yang dilaksanakan secara offline, masih ada sebanyak 14,7\% modul yang belum selesai. Modul ajar yang dibuat sudah baik, terlihat dari modul yang dibuat menarik, kontekstual, menggiring peserta didik menemukan jawaban sendiri sehingga modul yang dibuat telah memenuhi kriteria penyusunan modul yang baik dan menarik (Dikmenjur, 2004). Hal ini berarti peserta pelatihan telah memiliki keterampilan yang baik dalam membuat modul.

Secara keseluruhan materi dan metode yang digunakan dalam pelatihan ini dinilai baik oleh peserta. Pelatihan ini dapat menambah pengetahuan dan keterampilan peserta dalam membuat modul ajar. Namun, tidak hanya sebatas pelatihan, peserta diharapkan memiliki 
Kesumawati, N., Destiniar, D., Octaria, D., Ningsih, Y. L., Fitriasari, P., Mulbasari, A. S., Nopriyanti, T. D., Retta, A. M. (2021). Pelatihan pembuatan Modul Ajar bagi guru SMA/SMK di Tebing Tinggi. ABSYARA: Jurnal Pengabdian Pada Masyarakat, 2(2), $246-256$. doi:10.29408/ab.v2i2.4589

kemauan dan motivasi yang tinggi untuk mengembangkan kompetensi diri agar dapat menjadi seorang pendidik yang profesional (Sutikno, 2018).

\section{SIMPULAN}

Kegiatan ini bermanfaat untuk mengenalkan dan membekali pendidik tentang modul ajar. Selain itu, dengan adanya kegiatan ini dapat melatih keterampilan pendidik dalam membuat modul ajar. Implikasi dari kegiatan ini yaitu memberikan sumbangsih bagi pendidik dalam menghasilkan modul ajar yang efektif untuk digunakan dalam proses pembelajaran. Kegiatan PKM ini memiliki keterbatasan dalam membimbing peserta menyajikan materi pada modul ajar.

\section{PERNYATAAN PENULIS}

Artikel ini tidak pernah dimuat dalam jurnal pengabdian maupun jurnal penelitian sebelumnya.

\section{DAFTAR PUSTAKA}

Anwar, I. (2010). Pengembangan Bahan Ajar. Bandung: Direktori UPI.

Daryanto. (2014). Pendekatan Pembelajaran Saintifik Kurikulum 2013. Yogyakarta: Gava Media.

Dharma, S. (2008). Penulisan Modul, Kompetensi Penelitian dan Pengembangan. Jakarta: Departemen Pendidikan Nasional.

Dikmenjur. (2004). Pedoman Penulisan Modul. Jakarta: Dikmenjur, Depdiknas.

Hidayah, N. (2015). Pembelajaran Tematik Integratif di Sekolah Dasar. TERAMPIL (Jurnal Pendidikan dan Pembelajaran Dasar) , 2(1), 34-49.

Kholisho, Y. N., Arianti, B. D. D., Jamaluddin, J., Wirasasmita, R. H., Ismatulloh, K., Uska, M. Z., \& Fathoni, A. (2021). Pelatihan pembuatan dan editing video bagi guru SD untuk menghadapi Era Industri 4.0. ABSYARA: Jurnal Pengabdian Pada Masyarakat, 2(1), 119-127.

Millah, E. S., Budipramana, L. S., \& Isnawati. (2012). Pengembangan Buku Ajar Materi Bioteknologi di Kelas XII SMA IPIEMS Surabaya Berorientasi Sains, Teknologi, Lingkungan, dan Masyarakat (SETS). BioEdu , 1 (1), 19-24.

Mufidah, A. I., \& Susilawati, S. Y. (2020). Modul Bina Diri Tunagrahita untuk Meningkatkan Keterampilan Mengajar Guru Inklusif. Jurnal Ortopedagogia, 5(2), 107-110.

Nawawi, S., Antika, R. N., Wijayanti, T. F., \& Abadi, S. (2017, April). Pelatihan pembuatan modul ajar berbasis kurikulum 2013 untuk meningkatkan kemampuan berpikir kritis. In Prosiding Seminar Nasional Hasil Pengabdian kepada Masyarakat LPPM Universitas PGRI Madiun (pp. 42-46).

Nurmeidina, R., Lazwardi, A., \& Nugroho, A. G. (2021). Pengembangan Modul Trigonometri untuk Mengembangkan Kemampuan Pemecahan Masalah Matematika. Aksioma: Jurnal program studi pendidikan Matematika, 10(1), 15-27. 
Kesumawati, N., Destiniar, D., Octaria, D., Ningsih, Y. L., Fitriasari, P., Mulbasari, A. S., Nopriyanti, T. D., Retta, A. M. (2021). Pelatihan pembuatan Modul Ajar bagi guru SMA/SMK di Tebing Tinggi. ABSYARA: Jurnal Pengabdian Pada Masyarakat, 2(2), $246-256$. doi:10.29408/ab.v2i2.4589

Rachman, F. A., Sukaryawan, M., \& Sari, D. K. (2017). Pelatihan dan Pembimbingan Pembuatan Modul Bagi Guru Kimia SMA di Lubuk Linggau, Musi Rawas dan Musi Rawas Utara. Jurnal Pengabdian Sriwijaya, 7(2), 749-753.

Ramadhani, R., Mazaly, M. R., \& Setiawati, T. (2021). Pengembangan E-Modul Berbasis EPUB3 Sigil dalam Meningkatkan Kemampuan Techno-Pedagogical Guru Sekolah Menengah. JMM (Jurnal Masyarakat Mandiri), 5(3), 1024-1039.

Rigianti, H. A. (2020). Kendala Pembelajaran Daring Guru Sekolah Dasar Di Banjarnegara. Elementary School: Jurnal Pendidikan dan Pembelajaran ke-SDan, $7(2)$.

Samsuri, T., Muliadi, A., Muhali, M., Asy'ari, M., Prayogi, S., \& Hunaepi, H. (2020). Pelatihan desain media interaktif pada pembelajaran daring bagi dosen pendidikan biologi. ABSYARA: Jurnal Pengabdian Pada Masyarakat, 1(2), 64-69.

Septiani, A. (2016). Penerapan Asesmen Kinerja dalam Pendekatan STEM (Sains Teknologi Engineering Matematika) Untuk Mengungkap Keterampilan Proses Sains. Isu-Isu Kontemporer Sains, Lingkungan, dan Inovasi Pembelajaran , 654-659.

Sutikno, A. (2018). Upaya Peningkatan Kompetensi Guru Melalui Pengembangan Diri. Seminar Nasional IKA UNY (pp. 45-57). Yogyakarta: Universitas Negeri Yogyakarta.

Sutisna, U., \& Elkarimah, M. F. (2021). Pendampingan pengembangan keterampilan guru Sekolah Dasar dalam soal evaluasi pembelajaran dengan Teka-teki Silang berbasis smartphone. ABSYARA: Jurnal Pengabdian Pada Masyarakat, 2(1), 15-25.

Syamsuri, S., \& Nindiasari, H. (2021). Penguatan konsep matematis bagi guru matematika melalui pelatihan software Scilab secara daring. ABSYARA: Jurnal Pengabdian Pada Masyarakat, 2(1), 8-14.

Utami, T. N., Jatmiko, A., \& Suherman. (2018). Pengembangan Modul Matematika dengan Pendekatan Science, Technology, Engineering, And Mathematics (STEM) pada Materi Segiempat. Desimal: Jurnal Matematika , 1 (2), 165-172.

Zaenudin, M. (2015). Penerapan Model Pembelajaran Murder Terhadap Peningkatan Keterampilan Berfikir Kreatif Siswa Pada Konsep Pencemaran Lingkungan Di Kelas X Manu Putra Buntet Pesantren (Doctoral dissertation, IAIN Syekh Nurjati Cirebon).

Zuriah, N., Sunaryo, H., \& Yusuf, N. (2016). IbM guru dalam pengembangan bahan ajar kreatif inovatif berbasis potensi lokal. Jurnal Dedikasi, 13, 39-49. 